HOW

Volume 28, Number 3, pages 47 - 61

https://doi.org/10.19183/how.28.3.680

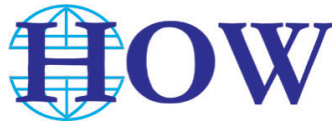

\title{
Language and Literacy Practices in Teacher Education: Contributions from a Local Agenda
}

\author{
Prácticas de Lenguaje y Literacidad en la Formación de Docentes: \\ Contribuciones desde una Agenda Local
}

\section{Amparo Clavijo-Olarte ${ }^{1}$}

\begin{abstract}
Language and literacy practices in teacher education are decisive in the education of future language teachers. In this article, I share my beliefs as a teacher educator about language and literacy practices constructed with teachers in Bogota. Thus, my intention is to weave my professional narrative through the connections I can make from theory and praxis to explain teachers' understandings of language and literacy through their life and literacy experiences and the way they organize their practice as language teachers. My research trajectory of thirty years documenting the local literacy practices within the research area of literacy studies and local pedagogies for social transformation has significantly informed my practice. University-school partnerships and international collaborations for research and teaching in Brazil, Chile, Costa Rica, Manchester, in the USA, and Dundee, in the UK, have nurtured me personally and professionally. My understanding of literacy as a social practice evolved to critical literacies and I developed knowledge in community pedagogies and city semiotic landscapes through reflections and collaborations via working with teachers. Community-based pedagogies (CBPs) invite teachers to see their life and work in relation to places they live and teach as meaningful content for linguistic, social, cultural, ecological, and economic resources to inspire students' inquiries and teachers' transformative practices. The city semiotic landscapes are powerful literacies for language learning; therefore, they currently adhere to the research group's agenda (2019-2021). I describe my understandings, contributions, and suggestions as concerns in the field of teacher education in
\end{abstract}

She is a professor of literacy and qualitative research and a researcher in the areas of Local Literacies and Teacher Education at Universidad Distrital Francisco José de Caldas in Bogotá, Colombia. Her most current research is on the city as curriculum: opportunities for literacies, ethnography, and pedagogy of place.

aclavijo@udistrital.edu.co

ORCID ID: https://orcid.org/0000-0002-3752-7020

Received: July 26 $6^{\text {th }}, 2021$. Accepted: August 9 $9^{\text {th }}, 2021$.

This article is licensed under a Creative Commons Attribution-Non-Commercial-No-Derivatives 4.0 International License. License Deed can be consulted at https://creativecommons.org/licenses/by-nc-nd/4.0. 
Colombia. My conclusions raise awareness about the need to address these topics in teacher education programs in Colombia.

Keywords: city literacies, community practices, language, literacy, teacher education

\section{Resumen}

Las prácticas lingüísticas y de alfabetización en la formación del profesorado son decisivas en la formación de los futuros profesores de idiomas. En este artículo, comparto mis creencias como formadora de maestros sobre las prácticas de lenguaje y alfabetización construidas con maestros en Bogotá. Por lo tanto, mi intención es tejer mi narrativa profesional a través de las conexiones que puedo hacer desde la teoría y la praxis para explicar la comprensión de los profesores del lenguaje y la alfabetización a través de sus experiencias de vida y alfabetización y la forma en que organizan su práctica como profesores de idiomas. Mi trayectoria investigadora de treinta años documentando las prácticas locales de alfabetización dentro del área de investigación de los estudios de alfabetización y las pedagogías locales para la transformación social ha informado significativamente mi práctica. Las asociaciones entre universidades y escuelas y las colaboraciones internacionales para la investigación y la docencia en Brasil, Chile, Costa Rica, Manchester, en los EE. UU. Y Dundee, en el Reino Unido, me han nutrido personal y profesionalmente. Mi comprensión de la alfabetización como práctica social evolucionó a alfabetizaciones críticas y desarrollé conocimiento en pedagogías comunitarias y paisajes semióticos de la ciudad a través de reflexiones y colaboraciones a través del trabajo con maestros. Las pedagogías basadas en la comunidad (PBC) invitan a los maestros a ver su vida y trabajo en relación con los lugares donde viven y enseñan como contenido significativo para recursos lingüísticos, sociales, culturales, ecológicos y económicos para inspirar las consultas de los estudiantes y las prácticas transformadoras de los maestros. Los paisajes semióticos de la ciudad son alfabetizaciones poderosas para el aprendizaje de idiomas; por tanto, actualmente se adhieren a la agenda del grupo de investigación (2019-2021). Describo mis entendimientos, contribuciones y sugerencias como preocupaciones en el campo de la formación docente en Colombia. Mis conclusiones generan conciencia sobre la necesidad de abordar estos temas en los programas de formación docente en Colombia.

Palabras clave: literacidad y ciudad, lenguaje, literacidades, formación del profesorado, prácticas comunitarias

\section{Introduction}

The narrative that depicts my professional and research trajectory addresses local issues in the fields of teacher education and literacy studies. Thus, I would like to start my personal and professional narrative by recognizing that my beliefs about language and literacy practices are informed by my experiences as a learner, as a teacher, engaging in professional development with other teachers, and by twenty years doing qualitative research. I believe that my personal experiences as a learner, teacher, teacher educator, and researcher have informed my teaching and shaped my identity as a bilingual person and teacher researcher through years of collaborative work. 


\section{As a Learner}

My beliefs about language teaching and learning have initially been constructed from experiences as a learner in primary, secondary, and university. Later, academic reflections through experiences as a research assistant in graduate school with Dr. Sarah Hudelson, documenting the biliteracy development of a group of second grade immigrant children in a public school in Phoenix, Arizona, informed my concept of language development (Spanish and English) as a social, cultural, and political phenomenon for the Mexican immigrants in Arizona in 1990. Experiences like the one mentioned here changed my perspective of teaching a second language to children; it taught me that learners make meaning from reading whole stories and making connections with lived experiences better than from learning isolated vocabulary or small, decontextualized parts of a text. Children, as second language learners, started interpreting a story by reading the images, predicting its contents, making connections with their funds of knowledge (Moll, et al, 1992), and using Spanish to share their interpretations of a story (Hudelson, 1984, 1989). The weekly data collection experience, learning with Dr. Hudelson about research and children learning at schools placed me in an optimal position as a novice researcher interacting with children and the teacher. This experience has informed my teaching of critical literacy and qualitative research in the graduate courses at Universidad Distrital Francisco José de Caldas and at local and international universities I have visited as a guest professor.

Zeichner (2012) considers that in college and university-based teacher education programs, making connections between campus courses and field experiences is important in order to balance theory and practice. Thus, I believe that the weekly field experiences as a novice researcher analyzing the biliteracy development of second grade immigrant Mexican children helped me make sense of the decontextualized theories of second language acquisition studied in the university classroom. Embracing the idea that theory informs but reflective practice has the power to transform and lead to action has made it my guiding principle in teacher education.

\section{As a Teacher Educator Doing Teacher Professional Development (TPD)}

A few years later in 1998, Esperanza Torres and I as faculty members at Universidad Distrital Francisco José de Caldas were asked by the Secretary of Education of Bogotá to put together a proposal for a one-year teacher professional development program (TPD) on literacy learning in Spanish and English. We offered it; fifty-eight Colombian teachers from public schools in Bogota enrolled and participated in the program. Esperanza Torres was the instructor. We provided the program with a structure by modules and a theoretical 
framework to understand, through teachers' life and literacy histories, the importance of family and social events in learning to read and write in early years. Teachers' literacy histories brought memories of their teachers and classroom activities; feelings towards critical people like parents and teachers; and the role of school in the life of teachers (See Goodman, 1980, as cited in Clavijo \& Torres, 1999).

Thus, I could theorize that teachers' knowledge of literacy is personal knowledge built from personal and professional experience. Connelly and Clandinin (1988) called it personal practical knowledge. Therefore, I believe that teachers' life and literacy histories are important resources, on the one hand, to analyze the ways teachers build their concept of literacy through life experiences; and on the other, to understand their decision-making for pedagogy and curriculum to foster students' literacy. The experience of having teachers write their life history as a source of pedagogical knowledge and of identifying their literacy experiences as a practical personal knowledge for their teaching was significant to them and to us as the teacher educators. Teachers also had the opportunity to have their students write their life histories and understand the literacy situations they were having in the classroom and at home. The narratives produced by teachers and children became powerful sources for reflection for teachers about their pedagogy and for children it provided room to learn about the centrality of connecting their personal story for learning in school.

\section{As a Teacher Educator and Researcher}

The TPD with the fifty-eight teachers became a powerful resource for teaching and research. I developed my doctoral research about teachers' knowledge of literacy in Spanish and English and gathered data such as teachers' life histories, classroom projects, and indepth interviews with them to create case studies of teachers. Since then (1998), I have been using life and literacy histories in my teaching to language teachers as tools to learn about their concepts and beliefs of literacy as sources that inform their practice. I consider that literacy histories can be a source to reflect with teachers about their own concepts of literacy, the role of language and literacy in their personal and academic life to address epistemological perspectives of critical literacy like Street's (1995) depadegogization of literacy in schools. His premise, along with Freire and Macedo's (1987) reading the world and the word, and Wells (1995) proposal to learn through inquiry, suggests the need to articulate language pedagogy and curriculum with learners' life and community knowledge through inquiry projects that can make learning meaningful to them. This connection between the individuals' life experiences and language pedagogy has geared my teaching and research to always consider the individual's experiences as central in the mission of making schooling meaningful for teachers and learners since our teaching should contribute to educate future citizens for a better Colombian society. 
I have presented my view of language and literacy as a learner, teacher, teacher educator, and novice researcher through personal and professional experiences engaging in teacher professional development between 1998 and 2000. Next, I share the main points of discussion that I address in this article as related to my teaching and research trajectory in language and literacy for language teacher education. My teaching and research from 2009 to the present spin around two topics: (1) Teacher education integrated in a community-situated agenda: using community as a resource and (2) Linguistic landscape projects as opportunities for learning beyond the classroom.

\section{Integrating Teacher Education in a Community-situated Agenda: Using Community as a Resource}

In this section, I would like to share details of a continuous international collaboration with Judy Sharkey from University of New Hampshire to carry out research with teachers in Bogota's public schools to promote knowledge of local community as resources for teaching and learning. The collaboration was initiated in 2008 at a conference in Medellin and has evolved throughout the years to our current ethnography and community-based pedagogy (CBP) project with schoolteachers, artists, and university students in the neighborhood of La Candelaria in Bogotá.

Our multiyear collaboration (2009-2021) initially focused on the following questions: What is the role of local knowledge in preparing language teachers in this time of globalized education reforms and standards? How do perceptions of community inform teachers' understanding of local? From our common interest of investigating community knowledge with teachers in Bogota, with the members of the research group Lectoescrinautas ${ }^{2}$, we proposed and carried out three research projects in five localities of Bogotá: Kennedy, Puente Aranda, San Cristobal, Mártires, La Candelaria, and Santa Fé. We studied local literacies as critical resources in teacher education to transform teaching and learning. Through action-research projects with urban teachers at public schools, we documented their ways of using community-based pedagogies to promote learning through an inquiry curriculum (For more details see Sharkey, 2012; Clavijo, 2015; Sharkey, Clavijo, \& Ramirez, 2016; Clavijo \& Ramirez, 2019).

The central aspects for language teacher education and research that we have learned through doing community-based pedagogies are related to (1) the practice-oriented focus of the field assignments for reflection, teaching, and research; (2) the generation of local knowledge

The members of the research group Lectoescrinautas are: Luz Maribel Ramírez, Judy Sharkey, Rosa Alejandra Medina, and Amparo Clavijo Olarte (Main Researcher). In the current project in the historic center (2019-2021), six students participated: Daniel Calderón Aponte, Alejandra Rodríguez B., Yuly Andrea Nieto, Kewin Arley Prieto, María Clara Nader, and Juan Camilo Rodríguez. Theresa Austin is the international advisor. 
for decision-making in curriculum and teacbing; (3) the transformative nature of critical and inclusive pedagogies like CBP that teaches teachers to recognize and make student and community assets the subject of curriculum (Comber, 2018); (4) and finally, the agentive role that teachers and learners take using CBP to connect school and community.

The field-assignments teachers do when physically or virtually mapping their community foster reflection for teaching and research because teachers move out of the comfort zone of the classroom and focus on the outside resources to contextualize language within the realities of the linguistic landscape in students' barrios. Teachers take agency towards designing meaningful curricula using the linguistic, social, and cultural resources available and engage students in learning about the social and cultural issues in their community.

Promoting community pedagogies for social transformation with teachers implied mapping the physical communities to identify the resources in the linguistic landscape for curriculum and teaching. This led us (Judy and I) to design and implement, between 2009 and 2011, new field-based assignments and to share them with our students, Judy's UNH students and my graduate students in Bogotá. Examples included my students' reflections in the advanced literacy seminar visiting the mega libraries in Bogota. In the visit, graduate students in Bogotá were expected to explore the array of literacy practices and opportunities available and create new types of community-based assignments for their students. Judy's students in Manchester focused on creating and teaching community-themed curriculum units in neighborhood centers to serve immigrant/refugee families and students (see Sharkey \& Clavijo-Olarte, 2012, for more detailed descriptions of assignments). My graduate students, embarking on community investigations near their teaching sites, reported that reading the UNH students' work helped them better understand the purpose and rationale of the assignment (Zeichner et al., 2014).

The field assignments carried out by graduate students in the critical literacy seminar promoted reflection on the ways to utilize local community resources to promote inquiry in the English class. It took teachers to slowly identify the deficit perspectives of teaching that they held (Comber \& Kamler, 2004) to get out of the deficit towards more positive and constructive views of students as capable learners with knowledge and experiences that are valuable for teaching and learning in classrooms. It also implied for teachers to position 52 local resources as meaningful for learning and inquiry and to connect local and global realities in ELT. Furthermore, the teacher education courses mentioned above fostered field explorations, written reflections, curricular design, innovative pedagogical projects, and classroom research by graduate students.

My advising a significant number of graduate students' theses on CBP generated local knowledge for decision-making in curriculum and teaching that had an impact on teachers and their institutions. CBP research with graduate students in different educational contexts 
in Bogota has been transformative for teachers and the teacher education field. Their research has addressed issues of social justice, inclusion of minority populations, and collaborative work with content area teachers.

A considerable portion of working with students' research projects and in my graduate and undergraduate teacher education seminars took place during the Covid-19 pandemic. It required my students and me to be thoughtful of the need to adapt instructional practices to meet the needs of their students and institutions. Equally important was to think of the most appropriate ways to carry out research activities with students while considering their possibilities and limitations as regards access to the Internet. These considerations corroborate the transformative nature of critical and inclusive pedagogies like CBP and promote the agentive role that teachers and learners take using CBP to address the common needs of students, families, school, and community in order to promote social justice in critical times of the Covid-19 pandemic.

My initial work in CBP transformed the conceptual and research understanding of English teachers who were my thesis advisees in the graduate program. In the development of the second project, a larger group of graduate students became teachers' leaders to implement CBP with content-area teachers from social studies, science, chemistry, English, and physical education in their public schools. Collaboratively, with my research group, we addressed the following questions: How do we help teachers value knowledge of local communities as rich resources for teaching and learning? How do community-based pedagogies affect the ways in which teachers connect their students' lives to their curriculum? (See Clavijo \& Ramirez, 2019, for more information). Collaborating with teachers in schools to help them gain knowledge about their local communities for teaching had significant impact on their professional learning as teacher researchers, in their institutions, and in the teacher education program at Universidad Distrital Francisco José de Caldas.

In the three research projects in which we explore the role of local knowledge in preparing language teachers, we have applied a sociocultural perspective to language and literacy in teacher education (LLTE) to theoretically inform our research. That view values the social and cultural resources and realities of the educational context of students and families for teaching and research. The theoretical contributions of Freire and Macedo (1987), Moll et al., (1992), and Ruiz (1984) have directly impacted my work as a teacher educator and researcher at Universidad Distrital Francisco José de Caldas as well as the work I have done with the research group in public schools in Bogotá during twenty-five years.

Similarly, our research acknowledges Johnson (2009) and Golombek and Johnson's (2011) conceptualization of teacher learning as a situated, collaborative, constructive, and transformative process. Including the local in the teacher education agenda also required us to consider a local perspective towards language policy and practice (Schecter, Solomon, \& 
Kitmmer, 2003; Canagarajah, 2005), and to foster a commitment among teachers to consider the community as relevant in teaching (Murrell, 2001). An informed perspective of the local social, cultural, and linguistic realities has contributed to making relevant decisions in language teacher education programs in critical ways by considering that we need to become aware of the colonizing spirit of the national linguistic policies towards English education. As such, we need to promote the construction of local knowledge that will connect to global initiatives for transformative, equitable, and inclusive pedagogies.

\section{Meaningful Collaborations towards the Implementation of Community-Based Pedagogy beyond the Local}

Beyond the local context of Bogotá, using the CBP framework became relevant to teacher educators and their students at three public universities at the national level. It was a great opportunity to share our interest to help teachers value knowledge of local communities as rich resources for teaching and learning with colleagues to think together about transformative ways for teaching and research in language teacher education programs. Thus, from 2017 to 2019, with colleagues from Universidad Industrial de Santander, Universidad del Tolima, and Universidad Pedagógica y Tecnológica de Colombia, we held two annual collegial encounters to share our epistemological perspective on teacher education using CBP and the outcomes of our projects with teachers in Bogota's schools.

International collaborations with colleagues from Brazil and Chile were also significant scenarios from which to share community-based teaching and research experiences in ways that reciprocally informed and complemented our interests and social commitment to public education in Latin America. For instance, I particularly value the contributions of peer Brazilian scholars on the multicultural and multilingual nature of city literacies. I have demonstrated the evident impact of including city literacies in public education institutions. I also value the continuous professional dialogue with Latin American peer researchers that nurture our professional interest and research.

I would like to highlight two key elements that have made my teaching and research trajectory a significant professional experience. The professional collaborations with colleagues from universities in some Colombian regions (Universidad Industrial de Santander, Universidad del Tolima, and Universidad Pedagógica y Tecnológica de Colombia), as well as The University of New Hampshire, and The University of Massachusetts-Amherst. All fostered collegial work and the development of research projects that inform teacher education. Our learning from projects also generated coauthored publications and presentations in conferences. The second aspect refers to the impact that these projects have generated towards teacher and learners' agency (Hernández, et al., 2020) since both teachers and learners become actively engaged in physically mapping their neighborhoods as a field assignment to identify their 
resources. This field assignment is geared towards the identification of social issues that can generate local inquiry and foster learners' local knowledge production at different educational levels. For example, the works of Nieto (2020), Clavijo \& Rincon (2016), Calderon-Aponte (2020), Rodriguez (2020), Gutierrez (2020), Gómez (2014), Clavijo \& Gómez (2020).

I have gained considerable learning from sharing with colleagues in national conferences, teaching seminars together at different universities, reading professional articles about the pedagogical value of using the linguistic landscape for teaching, and carrying out collaborative research projects through international collaborations about the relevance of investigating local literacies. During the last three years we have decided to delve into another major area of interest for language teacher education which is the multicultural and multilingual nature of the semiotic landscape in the city of Bogotá. With this ethnography we want to expand our understanding of the discourses and texts within city places for teaching. Therefore, in the following section I share the latest research project developed from 2019 to 2021.

More recently, my colleagues and I, in the research group that I lead, decided to embark on an ethnography (Pink, 2008) that aimed at documenting the multicultural nature of the linguistic landscape of the historic district of Bogotá as a resource for learning and teaching. We engaged with local people, artists, teachers, and university students to document multimodal texts and discourses that could inform instructional literacy practices in teacher education programs, (Lozano et al., 2020; Clavijo \& Austin, forthcoming).

\section{Linguistic Landscape Projects as Opportunities for Learning beyond the Classroom}

Because our experiences with CBP to integrate the community resources in language teacher education courses have been transformative for teacher educators, teacher researchers, and students, we consider that promoting linguistic landscape projects with teachers and students offers them meaningful opportunities for learning beyond the classroom; for example, Rodriguez's (2021) pedagogical project with EFL students analyzing the public university sociocultural landscape; Nieto's (2018) project with language students in a private university; Gutierrez's (2020) and Rincón's (2016) projects with high school students in public schools; Gómez's (2016) project with fifth-grade students; and González's (2012) project with Embera children at a public school to see the transformative dimension of their pedagogical and research experiences. The abovementioned projects began from pedagogical reflections in the critical literacy seminar that I teach every year and evolved into research projects that I oriented as a thesis director.

My group's current research project in the historic district in downtown Bogotá includes the perspectives of teachers, graffiti artists, and university students to document 
the multimodal and multicultural nature of the texts and discourses of La Candelaria and Santa Fe in the historic district. Thus, we posed the question: How does investigating Bogotá's historic center provide opportunities for learning about literacies, ethnography, and pedagogy of place? We used ethnography to analyze how local people engage with multimodal texts, and linguistic landscapes to inform instructional literacy practices in teacher education programs. In this regard, Lozano et al., (2020) believe that "connecting students' identities and experiences with authentic cultural and linguistic materials beyond the classroom holds great potential for language instruction because of the cognitively engaging and meaningful learning possible in these contexts" (p. 18).

Through this ongoing collaboration, we have expanded our understanding of the role that teachers assign to the linguistic, cultural, and social resources of their neighborhood for language learning, curriculum design, and pedagogy in schools in five localities of Bogotá: Kennedy, San Cristobal, Mártires, Puente Aranda, and La Candelaria and Santa Fe as part of the historic district of Bogotá. It has brought about change in the perception of language learning, literacy, curriculum, instruction, and students' and families' funds of knowledge. Evidence of change in teachers' thinking and practice is illustrated in the following testimony:

From my explorations of CBP I could see and practice how the community can be a multimodal book, for those who teach languages and their students who do not have access to paper books or high-tech equipment. Language was there on the walls, notices, flyers, adds [ads], family histories, songs, etc. After visiting and accompanying the teachers in their explorations of the community, I began to look at communities as learning resources. As a teacher, I could flesh out Freire's reading the world to reading the word. The family business, beauty parlors and local park full of willows and endemic plan $[\mathrm{t}]$ and animal species make better chemistry book $[\mathrm{s}]$ and labs to practice science, learn about botanic [botany], ecology and conservation than teachers' tests and dead scribbles on the whiteboard. I understood educational research is situated/community based. Researching $\mathrm{CBP}$ was an empowering process for teachers, students and for me as a novice teacher researcher. (Survey, Rosa Alejandra Medina, June 22, 2015) [sic]

Additionally, our explorations of the several texts in La Candelaria allowed us to conceive the city of Bogotá as a multimodal, multicultural, and multilingual "text" and context that is certainly worth reading and inquiring upon. We had the opportunity to become researchers within our own communities (Comber, 2015) which, through ethnographic and inquirybased processes, utilized the urban scenarios and communities as meaningful resources to foster language learning and teaching, as well as literacy development.

The text in the graffiti in English says, "On Bogotá Streets you can try, but you can't divide the tribe" (Image 1). It was taken at Carrera 4 and $17^{\text {th }}$ Street in Bogotá. Seeing how La Candelaria offers several texts written in languages other than Spanish, the official language of Colombia, was surprising for us. This suggests, as in Mora et al.'s (2018) study, that English and other languages are permeating the literacies and social spheres of our 


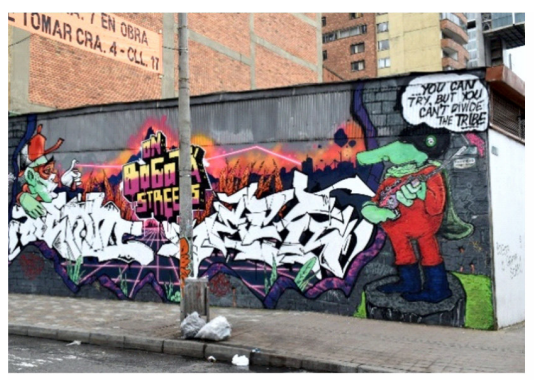

Image 1. On Bogotá Streets



Image 2. A child.

Photos taken by the research group Lectoescrinautas.

city. Image 2, taken in La Candelaria, is a mural of an indigenous child who seems to have been enrolled in the guerrilla groups because of the weapons that hang from his chest. His face shows frustration and sadness. Like him, many underage children are forced to join the armed groups in the territories in Colombia. Like these two images, many more in the historic center display political and ideological messages that denounce national problems of displacement or assassination of social leaders; multicultural texts that reveal our diverse population and cultures throughout Colombia; and socioeconomic problems that people are living due to unemployment or lack of opportunities to survive during the Covid-19 pandemic. I believe that the social, economic, and political situations revealed in multimodal texts in the public spaces in Bogotá can permeate the language curriculum and generate meaningful discussions and contextualized reading of Bogota's linguistic landscape.

Furthermore, doing ethnography of place became an opportunity for me to expand my perspective of doing qualitative research with social actors like artists, business owners, and university students and teachers. I believe that the visual ethnography of the places around schools in the historic center can promote student and teacher agency by visiting and documenting the texts of places in their cities and neighborhoods. It also provided insights about the political, social, and cultural dimensions of the semiotic landscape in the historic center of Bogotá. These dimensions of the semiotic landscape became relevant aspects for reflection in critical literacy, ethnography, and language teacher education seminars.

\section{The Impact of Using the Local Community Resources for Teaching and Research}

I consider that the topics of my academic work have strongly impacted other authors and studies in Colombia. The studies framed on critical literacies, CBP, and semiotic landscape have addressed and provided transformative teaching and learning possibilities for 
critical populations in public education. My research on critical literacy with teachers (which includes families and local communities) has shown to be of primary importance during the Covid-19 pandemic. Within a year and a half of the Covid-19 pandemic, teachers have had to move from face-to-face teaching to distant teaching mediated by internet platforms. This situation has represented struggles for teachers, students, and families. In public schools in Bogota and the rural contexts the situation is worse since many children do not have internet connectivity and they have not had access to education for that time. The CBP framework that connects out-of-school literacies with the school curriculum fosters collaborative work with parents to help children learn. The pandemic has been a good opportunity for schoolparent collaboration towards a transformative pedagogy. Thus, teacher education courses that we, teacher educators, guide should address the current needs of teachers transitioning from face-to-face teaching to remote teaching and back to a different alternating face-toface teaching (for further information on this project, see Gómez's (2020) Multimodal Narratives and Students' Voices in Community Practices in Times of Covid-19). My studies have connected critical literacies with CBP in ways that have provided new understandings in teacher education. I have raised awareness about the invisible voices of linguistic minority students as the missing voices of the current language education policies in the country. In the work with Gonzalez (2014), one of my graduate students, it has been evident that the curriculum as a multicultural and multilingual project for schools with indigenous children contributes to change the monolingual perspective of the school and teachers within this project. A primary contribution of my research that has influenced graduate students' thinking and teaching has to move out of traditional and deficit-oriented discourses in language teaching towards a more positive and inclusive teaching that values the knowledge that students built within families for learning. In my teaching I have provided teachers with opportunities for meaningful learning beyond the classroom that has impacted many young learners in schools, language centers, and universities.

Finally, the powerful narratives that teachers and teacher educators have constructed around language and literacy practices in teacher education evidence the relevance of viewing students as capable learners at all levels of education; of using the resources from the linguistic landscape of their communities to learn languages and to think critically about the resources in their barrios; of revealing teacher and learner agency by doing local inquiry and constructing locally relevant knowledge; and of creating opportunities for students and parents to write multimodal narratives.

\section{Conclusions}

This article has allowed me to reveal the impact of critical reflection in the construction of local agendas for teacher education. I suggest that teacher education programs should 
orient their curriculum to practice-based frameworks. More field assignments are required for teachers to go outside of the classroom and map the resources of the community to connect them with their teaching. Relating school, family, neighborhoods, and communities promotes teacher agency by engaging teachers and students in reflection and inquiry. These are lenses which allow them to construct informed decisions by situating language practice in connection with the realities of the city in which learners and teachers live and learn (Lozano et al., 2020).

In my research trajectory, I have demonstrated that research as a learning experience requires adopting a critical and a participatory approach. The critical stance refers to the ways to comprehend the complexities of the data in the collection and analysis process. The participatory aspect, on the other hand, includes the epistemological negotiations among the members of the group that need to be mediated through horizontal relationships established by researchers. Finally, I have shown the significance of professional academic collaborations. The results of collaborations with teacher educators build strong research communities of practice and interest. The valuable interactions of my research group generate a great deal of learning together towards common goals when working directly with teachers, families, community members, and international colleagues. Thus, if we sustain solid communities of practice and interest, we can obtain enriching and diverse perspectives that orient teaching and research on teacher education.

\section{References}

Canagarajah, A. S. (Ed.). (2005). Reclaiming the local in language policy and practice. Routledge.

Clavijo, A. (2015). Implementing community-based pedagogies with teachers in Colombia to enhance the English curriculum. In M. Perales \& M. Méndez (Eds.), Experiencias de docencia e investigación en lenguas extranjeras (pp. 31-43). Editorial Universidad Quintana Roo.

Clavijo, A., \& Torres, E. (1999). Memorias del Congreso Colombiano de Lecto-escritura en lengua materna y lengua extranjera para un nuevo siglo. Cargraphic.

Clavijo-Olarte, A., \& Austin, T. (Forthcoming). Crossing multilingual boundaries with powerful literacies: A collaborative ethnography in the linguistic and socio-economic landscape of downtown Bogotá. In A. de Mejía, N. Miranda, \& S. Valencia Giraldo (Eds.), Critical perspectives and voices from the field in multilingual Colombia.

Clavijo-Olarte, A., \& Galindo, L. M. R. (2019). Las pedagogías de la comunidad a través de investigaciones locales en el contexto urbano de Bogotá. Universidad Distrital Francisco José de Caldas.

Clavijo-Olarte, A., \& González, Á. P. (2016). The missing voices in Colombia bilingüe: The case of Embera children's schooling in Bogotá, Colombia. In N. Hornberger (Ed.), Honoring Richard Ruiz and bis work on language planning and bilingual education (pp. 431-458). Multilingual Matters. 
Comber, B. (2015). Critical literacy and social justice. Journal of Adolescent \& Adult Literacy, 58(5), 362-367.

Comber, B. (2018). Community-based approaches to foreign language education. Colomb. Appl. Linguist. J., 20(2), 153-160.

Comber, B., \& Kamler*, B. (2004). Getting out of deficit: Pedagogies of reconnection. Teaching education, 15(3), 293-310.

Connelly, F. M., \& Clandinin, D. J. (1988). Teachers as curriculum planners. Narratives of Experience. Teachers College Press.

Freire, P., \& Macedo, D. (1987). Literacy. Reading the word and the world. Bergin and Garvey.

Gómez, J. (2016). Collaborative inquiry as a way to promote elementary students' reflections in the EFL classroom [Unpublished master thesis]. Universidad Distrital Francisco José de Caldas.

Gómez, M. D. (2020). Multimodal texts production in language teacher education school family connections in times of Covid-19 [Unpublished master thesis]. Universidad Distrital Francisco José de Caldas.

González, A. P. (2014). Embera immigrant children schooling process in Bogotá [Unpublished master thesis]. Universidad Distrital Francisco José de Caldas.

Goodman, Y. M. (1980). The roots of literacy. Paper presented at the Annual Meeting of the Claremont Reading Conference (47th, Claremont, CA, January 18-19, 1980).

Gutiérrez, D. (2020). Problematizing the community: Voices from secondary school students [Unpublished master thesis]. Universidad Distrital Francisco José de Caldas.

Hernández Varona, W., \& Gutiérrez Álvarez, D. F. (2020). English language student-teachers developing agency through community-based pedagogy projects. Profile: Issues in Teachers' Professional Development, 22(1), 109-122.

Hudelson, S. (1984). Kan yu ret an rayt en ingles: Children become literate in English as a second language. TESOL quarterly, 18(2), 221-238.

Hudelson, S. (1989). Write On: Children writing in ESL. Prentice Hall Regents.

Johnson, K. E. (2009). Second language teacher education: A sociocultural perspective. Routledge.

Johnson, K. E., \& Golombek, P. R. (2011). The transformative power of narrative in second language teacher education. TESOL Quarterly, 45(3), 486-509.

Lozano, M. E., Jiménez-Caicedo, J. P., \& Lee, B. A. (2020). Linguistic landscape projects in language teaching: Opportunities for critical language learning beyond the classroom. In D. Malinowski et al., (Eds.), Language teaching in the linguistic landscape, educational linguistics. Springer. https://doi.org/10.1007/978-3-030-55761-4_2

Moll, L., Amanti, C., Neff, D., \& González, N. (1992). Funds of knowledge for teaching: Using a qualitative approach to connect homes and classrooms. Theory into Practice, 31(2), 132-141.

Mora, R. A., Pulgarín, C., Ramírez, N., \& Mejía-Vélez, M. C. (2018). English literacies in Medellín: The city as literacy. In S. Nichols \& S. Dobson (Eds.), Learning cities: Cultural studies and transdisciplinarity in education (pp. 37-60). Springer Nature. 
Murrell, P. (2001). The community teacher: A new framework for effective urban teaching. Teachers' College Press.

Nieto, Y. (2020). Promoting the use of local literacies among EFL university teachers: Sources to connect curriculum and teaching [Unpublished master thesis]. Universidad Distrital Francisco José de Caldas.

Pink, S. (2008). An urban tour: The sensory sociality of ethnographic place-making. Ethnography, 9(2), 175-196.

Rincón, J., \& Clavijo-Olarte, A. (2016). Fostering EFL learners' literacies through local inquiry in a multimodal experience. Colomb. Appl. Linguist. J., 18(2), 67-82.

Rodríguez, A. (2021). EFL learners' agency exploring the sociocultural landscape of a public university [Unpublished master thesis]. Universidad Distrital Francisco José de Caldas.

Ruiz, R. (1984). Orientations in language planning. NABE journal, 8(2), 15-34.

Schecter, S., Solomon, P., \& Kittmer, L. (2003). Integrating teacher education in a communitysituated school agenda. In S. Schecter \& J. Cummins (Eds.), Multilingual education in practice: Using diversity as a resource (pp. 81-96). Heinemann.

Sharkey, J. (2012). Community based pedagogies and literacies in teacher education: Promising beginnings, intriguing challenges. Ikala, 17(1), 9-13.

Sharkey, J., \& Clavijo, A. (2012). Community-based pedagogies: Projects and possibilities in Colombia and the United States. In A. Honigsfeld \& A. Cohan (Eds.), Breaking the Mold of Education for culturally and linguistically diverse students (pp. 129-137). Rowman \& Littlefield Publishers Inc.

Sharkey, J., Clavijo, A., \& Ramírez, M. (2016). Developing a deeper understanding of communitybased pedagogies with teachers: Learning with and from teachers in Colombia. Journal of Teacher Education, 67(3), 1-14.

Street, B. (1995). Social Literacies: Critical approaches to literacy in development, ethnography and education. Longman.

Wells, G. (2000). Dialogic inquiry in education: Building on the legacy of Vygotsky. In C. D. Lee \& P. Smagorinsky (Eds.), Vygotskian perspectives on literacy research (pp. 51-85).

Zeichner, K., Payne, K. A., \& Brayko, K. (2014). Democratizing teacher education. Journal of Teacher Education, 66(2), 122-135. https://doi.org/10.1177/0022487114560908

Zeichner, K., Payne, K., \& Brayko, K. (2012). Democratizing knowledge in university teacher education through practice-based methods teaching and mediated field experience in schools and communities. Harvard Educational Review, 1-46. 